\title{
UMA DANÇA DOS CORPOS FÍLMICOS
}

\author{
A FILMIC BODIES DANCE
}

UNA DANZA DE LOS CUERPOS FÍLMICOS

Ingrid Rodrigues Gonçalves

\section{RESUMO}

Este ensaio visa tecer linhas transversalmente, com uma perspectiva pós-estruturalista. Evocamos como intercessores, pensadores como Gilles Deleuze, Giorgio Agamben, Ana Francisca de Azevedo; cineastas, técnicos e projecionistas, tendo nestes últimos, um estudo de caso que enlaça nossas ponderações, produzindo espécie de falcaça nos fios que puxamos. Desenvolvemos uma reflexão sobre os corpos como suportes e sobre os suportes como corpos. Levamos em conta que: os movimentos de nosso pensamento, podem atuar de modo semelhante aos projetores cinematográficos, dispondo imagens no tempo, nas "telas" de nossas vidas; há um processo em curso de substituição do suporte padrão cinematográfico, do filme fotoquímico para os pixels; películas e seus agenciamentos estão sendo substituídos pelo cinema digital, que demanda e produz corpos com outras trajetórias, singrando novos campos de possíveis no que tange às produções audiovisuais, pois as imagens digitais por se tratarem de pontos fotográficos binários podem ser copiadas e modificadas "ad infinitum", descerrando possibilidades estéticas; por sua volta, experimentações dos modos de fazer relacionados à película constituem-se como experiências singulares, que percorrem outras linhas. Esta é uma discussão de vulto na contemporaneidade, tendo em vista que a transição tecnológica tem desterritorializado os saberes relacionados ao fazeres cinematográficos com película fotoquímica e, noutro turno, que nossas relações interpessoais têm sido cada vez mais mediadas por imagens-projetadas em telas e sua produção via corpos-pixel, em variados dispositivos.

PALAVRAS-CHAVE: Cinema. Corpo. Subjetividade.

\begin{abstract}
This essay aims to accomplish a transversal analysis with a post-structuralist approach. We invoke as intercessors, thinkers such as Gilles Deleuze, Giorgio Agamben, Ana Francisca de Azevedo, filmmakers, technicians and projectionists, the latter, a case study that links our reflections, producing kind of whipping knot in the wires pulled. We develop a reflection about bodies as films and films as bodies. We take into account that the movement of our thoughts, can act similarly to movie projectors, providing images in time, at our lives "screens"; there is a process accuring, a replacement of photochemical film, as standard film format, to pixels; celluloid and its assemblages are being replaced by digital cinema, which demands and produces bodies with other paths, plowing through new possible fields in relation to audiovisual works because digital images beeing binary photographic points, can be copied and modified "ad infinitum", unsealing aesthetic possibilities; in its turn, experiments of the "ways to do" related to film constitute as singular experiences that run along other lines. This is an important discussion nowadays, considering that the technological transition has deterritorialized the knowledge related of doing cinema with photochemical film and, in other hand, that our interpersonal relations have been increasingly mediated by images-projected on screens and their production via pixel-body, in various devices.
\end{abstract}

KEYWORDS: Cinema. Body. Subjectivity 


\section{RESUMEN}

Este ensayo tiene como objetivo tejer líneas transversales con una perspectiva post-estructuralista. Invocamos como intercesores, pensadores como Gilles Deleuze, Giorgio Agamben, Ana Francisca de Azevedo; realizadores, técnicos y proyectistas, estos últimos, un estudio de caso que une nuestros pesos, produciendo especie de falcaceadura en los hilos que tiramos. Desarrollamos una reflexión sobre los cuerpos como soportes y los soportes como cuerpos. Tenemos en cuenta que: los movimientos de nuestro pensamiento, pueden actuar de manera similar a los proyectores cinematográficos, disponendo imágenes en tiempo, en las "pantallas" de nuestras vidas; hay un proceso en marcha para sustituir el soporte estándar cinematográfico, da película fotoquímica a píxeles; películas y sus ensamblajes están siendo reemplazados por el cine digital, que demanda y produce cuerpos con otros caminos, arando través de nuevos campos de posibles en relación a las obras audiovisuales porque las imágenes digitales porque son puntos fotográficos binarios pueden ser copiados y modificados "ad infinitum" descerrando posibilidades estéticas; experimentaciónes de las formas hacer en relación con la película constituyen experiencias únicas que se ejecutan a lo largo de otras líneas. Esta es una discusión importante hoy en día, teniendo en cuenta que la transición tecnológica ha desterritorializado los conocimientos relacionados con las formas de hacer con la película fotoquímica y que nuestras relaciones interpersonales han sido cada vez más mediadas por imágenes, proyectadas en las pantallas y su producción través de los cuerpos-píxel en varios dispositivos.

PALABRAS ClAVE: Cine. Cuerpo. Subjetividade. 


\section{PRÉVIAS}

O cinema não reproduz corpos, ele os produz com grãos, que são grãos de tempo (Gilles Deleuze)

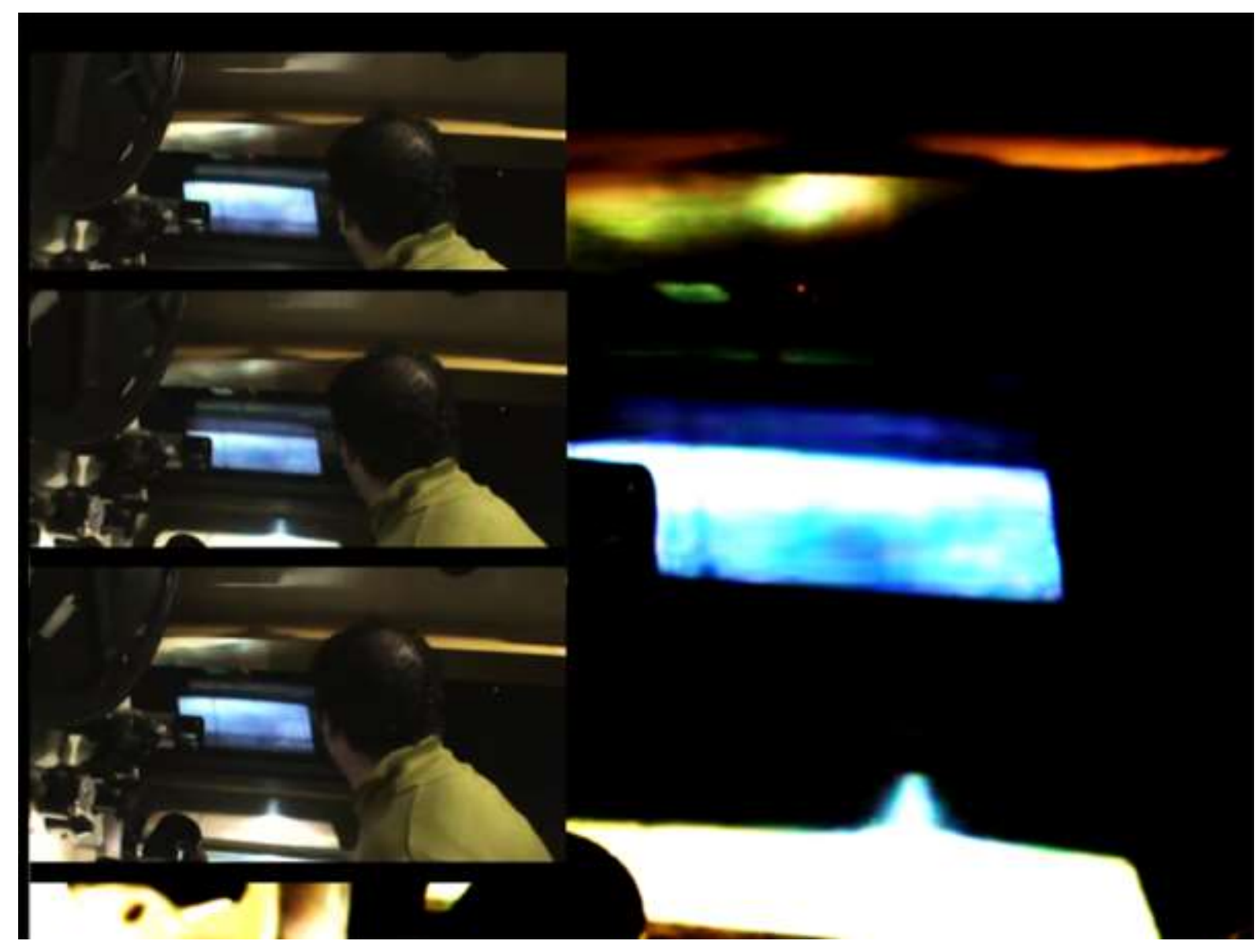

IMAGEM 1 - Um fora-quadro.

Fonte: [Montagem nossa com frames do curta-metragem Balé Mecatrônico]

Desconectar-se. Desligar o celular. Agenciar-se à sala escura. Um espetáculo ao vivo. Sala lotada. "Boa sessão!". Casais apaixonados, teenagers, críticos e "comedores de pipoca": todos acomodados em suas poltronas numeradas e mergulhados no ecrã. Na cabine de projeção, o operador cinematográfico baila na escuridão, interagindo com imagens, espaço, maquinário e com seu próprio corpo. O filme, incubado enquanto suporte, emerge na tela, após trafegar pelas linhas de trabalho deste projecionista. Na imagem 1, uma montagem com três fotogramas do curta-metragem "Balé Mecatrônico"1, cujas imagens foram captadas na cabine de projeção da Sala BNDES, uma das salas de cinema da Cinemateca Brasileira, em São Paulo. No projetor, a película percorre trilhos e roldanas entre uma bobina e outra. A luz

1 “Balé Mecatrônico". Disponível em: <https://www.youtube.com/watch?v=WKNmcGVR8iE>. Acesso em: 12/08/2016. 
da lâmpada xênon, de aproximadamente $3000 \mathrm{~W}$ atravessa os fotogramas em movimento, impulsionando a imagem a trespassar a lente de aumento, rumo à tela branca. $\mathrm{O}$ corpo do projecionista mistura-se entre sala de cinema e cabine de projeção, à espreita de referências da sala, o que nos indicam os movimentos sutis e precisos de seu corpo, semelhando uma dança. Na Imagem 1, destacamos um átimo da sessão, um "fora-quadro", que poderia ter comprometido o andamento do espetáculo e demandou um ajuste ágil do projecionista.

Um "fora-quadro", é um descompasso no transitar da película durante a projeção. Cada quadro (frame) de um filme em $35 \mathrm{~mm}$, possui em suas laterais quatro perfurações. Além da imagem, pistas de som analógico e digital (ver Imagem 2). Quando um projecionista emenda os rolos do filme e carrega o projetor para exibição, precisa atentar para encaixar corretamente os furos da película aos trilhos da máquina, pois dado o atrito inerente ao percurso do filme no projetor, o corpo fílmico pode desviar da rota.

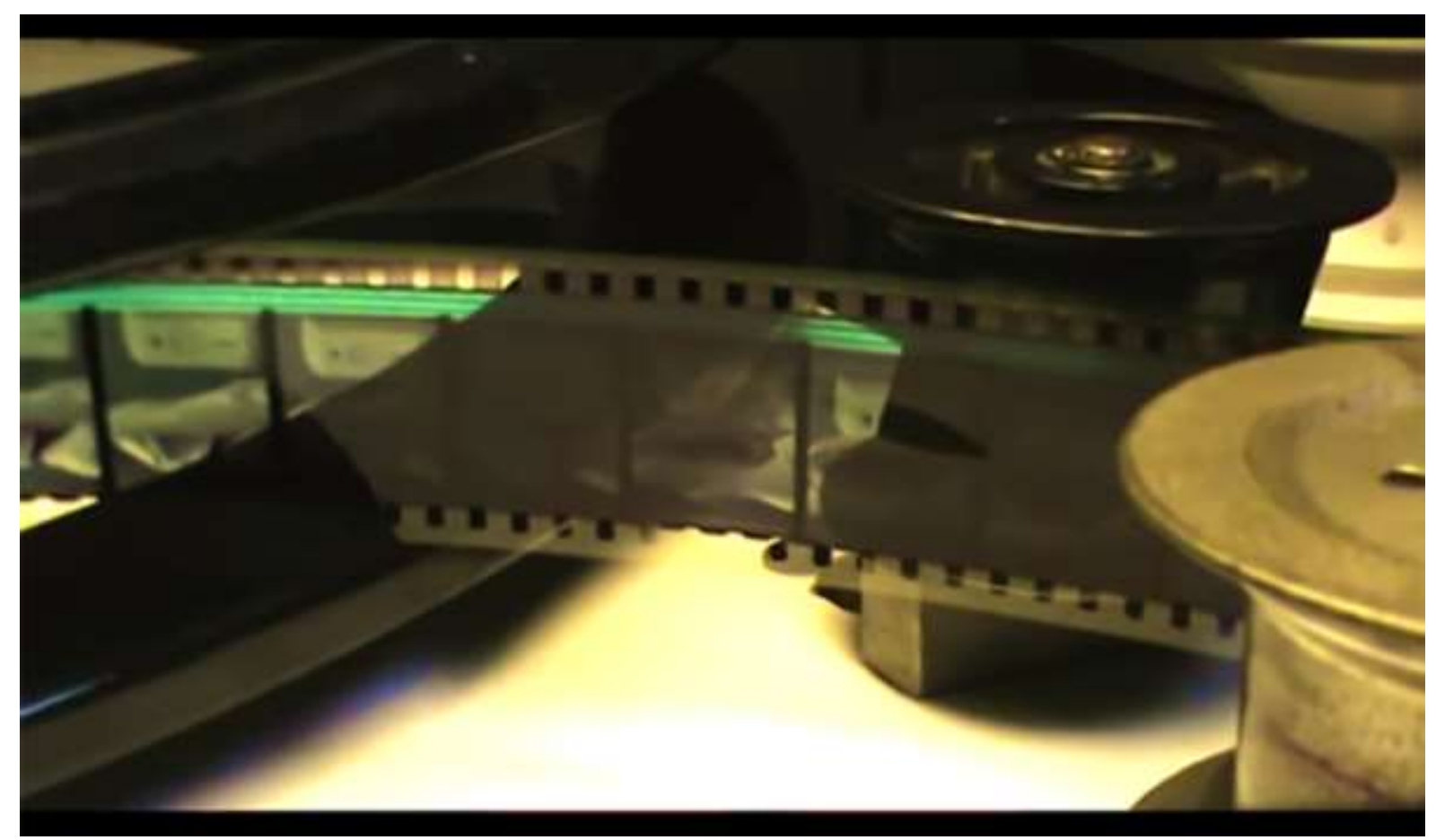

IMAGEM 2 - Um corpo-película.

Fonte: [Frame do curta-metragem Balé Mecatrônico]

Durante uma exibição, a película pode descarrilhar desta ordem dos furos, ou por uma emenda mais grossa entre os rolos do filme, ou por ocorrências mecânicas, ou simplesmente por imprevistos. Um "fora-quadro" pode acontecer decorrente de algum desses desencaixes entre trilhos e corpo-película, de modo que a imagem divide-se na tela, com um risco preto ao meio: vemos a fronteira entre um frame e outro invadindo a imagem-projetada. Daí o espasmo, impulso que o leva a agir rapidamente para aplanar a possibilidade de rebentação do que pulula, de modo que o descarrilho não perturbe o espetáculo. O projecionista, agenciase rapidamente à máquina, restituindo ao movimento fílmico sua ordem anterior, "perfeitamente" encaixada aos trilhos. "Puro reflexo! Não é racional! Você dá um pulo e 
faz!"'2. O fora-quadro que vemos no curta aconteceu num momento em que o operador estava ladeando a máquina, o que aligeirou o ajuste. Na Imagem 1, enfileiramos verticalmente 3 frames sequenciais, localizados aos 10'22”, na tentativa de expor essa invasão da borda preta na tela. O ligeiro agenciamento "projecionista + película + projetor" vindica do operador, para além da visão, audição e tato, um corpo háptico, que se misture às linhas da cabine de projeção. O háptico "é um termo melhor do que tátil, pois não opõe dois órgãos dos sentidos, porém deixa supor que o próprio olho pode ter essa função que não é óptica" e, um espaço háptico, "pode ser visual, auditivo, tanto quanto tátil”" (Deleuze e Guattari, 2012, p. 217).

Máquinas, imagens e projecionista: corpos humanos e não humanos conectados. Ali, naquele átimo, preciso como um médico que cuida da vida de seu paciente durante uma cirurgia. O médico, cuida de uma vida que habita o tempo nas 24 horas dos dias; o projecionista, da linha que pulsa a 24 quadros por segundo, das sensações em jogo naquela sala de cinema. Em outro momento, na mesma cabine de projeção, percebemos que ao "centro cirúrgico" cinematográfico contemporâneo, além da projeção com películas fotoquímicas, somam-se outros elementos.

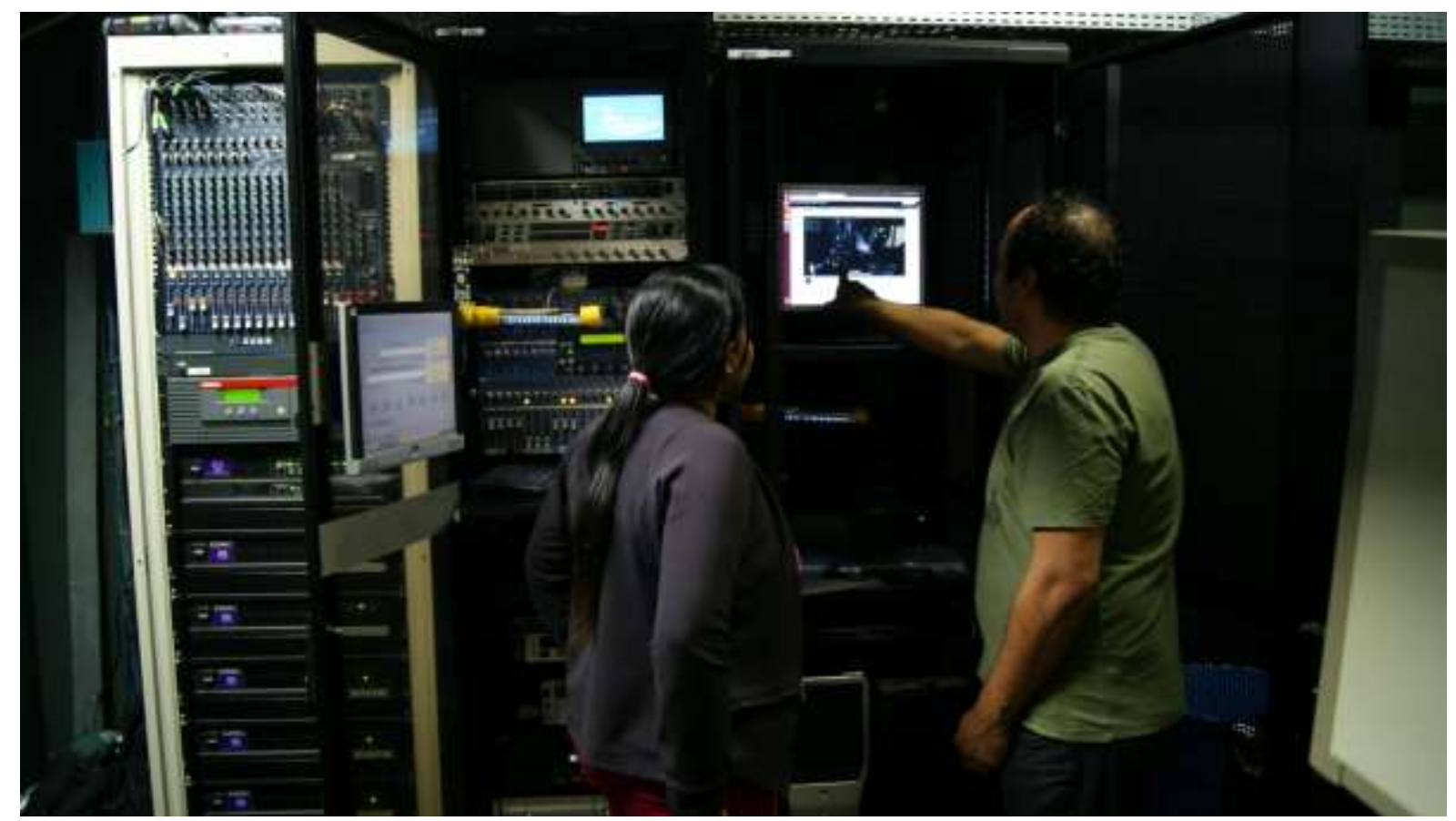

IMAGEM 3 - A luz dos vaga-lumes, 16.

Fonte: [nosso acervo (A luz, 2015)]

No canto direito, a quina de um dos projetores de películas $35 \mathrm{~mm}$ recorda-nos que apesar de todos os cabos e botões enquadrados, a projeção mecânica ainda habita esse espaço. Na Imagem 3, não estamos ao vivo, os projecionistas estão nas prévias de um espetáculo, entre telas, playlists, players, mesas de som, compressores, microfones, etc, preparando a

\footnotetext{
${ }^{2}$ Excerto obtido por conversa com os projecionistas Alexandro Nascimento Genaro e Carmen Lúcia Genaro, dia 31/07/2016, cujos entrevistados assinaram termo de concessão.
} 
sessão que não moverá películas, mas um pacote digital de arquivos. O gesto da mão que se mistura com a imagem da tela do computador, é antagônico ao vigor encarnado ao vivo, como percebemos no curta: um corpo elástico e háptico, dançando na escuridão para cuidar da vida do espetáculo.

Iniciamos com estas três imagens, intendendo urdir o espaço. Propomos uma reflexão sobre como as mudanças nesses grãos de tempo, os "corpos fílmicos" - ou também poderíamos chamar de suportes fílmicos -, podem promover desterritorializações nos modos de fazer e pensar o cinema, outrossim, nas maneiras como percebemos as imagens no contemporâneo. Compreendemos o espectar uma sessão de cinema "como um lugar vivenciado" (Azevedo, 2007, p. 13), uma experiência singular entre espectador e imagemprojetada, que, dadas as mudanças nos modos de fazer e pensar o cinema, amplifica-se em possibilidades, "um acto de visão em que a observação se encontra em relação íntima com os demais sentidos, com um sistema de emoções e com um corpo, para se afirmar como uma visão háptica e não óptica" (Idem, p.21). Mais: a percepção fílmica não se resume ao gesto de olhar e ouvir, as tecnologias também compõem com nossos corpos outras camadas sensórias.

Este ensaio visa tecer linhas transversalmente, com uma perspectiva pósestruturalista. Evocamos como intercessores, pensadores como Gilles Deleuze, Giorgio Agamben, Ana Francisca de Azevedo; cineastas, técnicos e projecionistas, tendo nestes últimos, um estudo de caso que enlaça nossas ponderações, produzindo espécie de falcaça nos fios que puxamos. Desenvolvemos uma reflexão sobre os corpos como suportes e sobre os suportes como corpos. Levamos em conta que: os movimentos de nosso pensamento, podem atuar de modo semelhante aos projetores cinematográficos, dispondo imagens no tempo, nas "telas" de nossas vidas; há um processo em curso de substituição do suporte padrão cinematográfico, do filme fotoquímico para os pixels; películas e seus agenciamentos estão sendo substituídos pelo cinema digital, que demanda e produz corpos com outras trajetórias, singrando novos campos de possíveis no que tange às produções audiovisuais, pois as imagens digitais por se tratarem de pontos fotográficos binários podem ser copiadas e modificadas "ad infinitum", descerrando possibilidades estéticas; por sua volta, experimentações dos modos de fazer relacionados à película constituem-se como experiências singulares, que percorrem outras linhas. Esta é uma discussão de vulto na contemporaneidade, tendo em vista que a transição tecnológica tem desterritorializado os saberes relacionados ao fazeres cinematográficos com película fotoquímica e, noutro turno, que nossas relações interpessoais têm sido cada vez mais mediadas por imagens-projetadas em telas e sua produção via corpos-pixel, em variados dispositivos.

Conforme o tecemos, percebemos este texto como um ensaio, inclusive pelo gesto de dispor nosso próprio corpo à passagem desses cruzamentos, não como um lugar de origem, mas como um espaço que permite o atravessamento desses fluxos, dessas imbricações contemporâneas entre cinemas, imagens, percepções hápticas, movimentos, subjetividades, tecnologias, que talvez, venham a "operar noutros caminhos de investigação, escrita e criação 
de imagens, e sons e..." (Azevedo, Ramírez e Oliveira Jr, 2015, p. 16). Não intendemos esgotar tais temas, mas deixá-los passar, numa tentativa "de dar conta não apenas da esfera discursiva de uma viagem intelectual, mas também do seu próprio fabrico" (Azevedo, 2007, p. 30-31).

\title{
2 IMAGENS DANÇARINAS
}

Uma imagem impressa difere de uma imagem projetada, pois esta última apenas é vivenciada onde há um projetor que a anime e, apesar de existirem máquinas portáteis, a interação com a luz difere, dado que uma imagem impressa necessita de incidência luminosa por ser "perceptivamente falando, apenas uma superfície refletora; a imagem projetada traz consigo a própria luz e requer, ao contrário, que se eliminem outras fontes luminosas, que vêm enfraquecer a luz inerente à imagem” (Aumont, 1995, p. 176).

A ideia de "corpo fílmico", como tecida em Barbosa (2015), dialogando com o conceito de corpo em Deleuze (2002), entrecruza-se com o que temos chamado de "imagemprojetada" e seus agenciamentos possíveis com os espectadores.

\begin{abstract}
o documentário como um corpo fílmico, entendido como certo regime de relação entre elementos, quais sejam: pessoas, lugares, objetos, paisagens, planos, tempos que criam um arranjo imagético a partir do modo como o cineasta enquadra, monta e compõe seus filmes, onde se produzem linhas duras, erráticas e de fuga. Um corpo fílmico configurado pelo modo como a linguagem cinematográfica é explorada pelo diretor, e pelas relações criadas com um corpo espectador. (Barbosa, 2015, p. 335).
\end{abstract}

Experienciar essas relações em uma sessão de cinema, requer uma experimentação espacial mais demorada e intensa, "um olhar dilatado no tempo e no espaço, requer deixar 'ser pego"' (Cazetta, 2013, p. 21), como as coreo-geo-grafias do filme Pina (2011), de Win Wenders, 'pegaram' Cazetta (2013). Sensações que habitaram seu corpo em uma sessão de cinema e fizeram a geógrafa dançar sem se mexer, transportando-a "para um espaço-tempo, onde somente a potência de vida seria a responsável por definir os movimentos corpóreos, pois a intensidade de uma dada experiência pode e cria geografias" (Idem, p. 22). Ela descreve como essas sensações alargaram-se por vários dias, de modo que produziram "um desejo imenso de escrever algo sobre o filme, bem como acerca das sensações" (Idem, p. 21).

Subindo as escadas, enquanto as sensações "dançam" na plateia, um outro ritmo de bailado acontece em uma cabine de projeção. Ao projecionista, cabe resguardar os agenciamentos entre os que "dançam sem sair do lugar" e as imagens-projetadas. Assim, as imagens são tanto o material de trabalho como também o brilho resultante de seu ofício, cadenciado pelo pulsar das máquinas e pelo trilhado dos corpos fílmicos, que movem, ao vivo, linhas contingenciais nos espaços da cabine de projeção e do corpo do operador. Um projecionista, num contexto de projeções em filme fotoquímico, precisa dispor de diversos saberes para manejar uma cabine de projeção. Sloane (1922) enfatizou a importância dos conhecimentos de eletricidade como sendo essenciais a um "bom operador", dado que a produção da luz, bem como os mecanismos das máquinas, são alimentados por cargas 
elétricas. "Mas deixe algo acontecer e então seu conhecimento de eletricidade será provavelmente invocado e ele terá provavelmente que pensar rápido, enquanto a audiência está esperando pela continuação da exibição" (Sloane, 1922, p. 26, tradução nossa). Além da eletricidade, há muito mais envolvido, o projetar é a menor parte do trabalho de um profissional da projeção de filmes, sendo preciso perfilar-se também por entre "as leis da radiação da luz e da iluminação, os princípios da projeção ótica [...] aprender o mecanismo da máquina de projeção" (Idem, p. 26), objetivando por fim, que a fina película percorra seus caminhos através da cabine.

Numa ponta de seu processo cotidiano, o operador recebe as "imagens-suporte", os filmes, que podem chegar em diferentes formatos (películas, arquivos digitais, fitas, etc). Noutro cume, a "imagem-projetada", corporizada no momento do espetáculo, consubstancia seu trabalho. No meio, entre imagem-suporte e imagem-projetada, no momento do espetáculo, o projecionista permanece à espreita, resguardando possibilidades de agenciamentos entre imagem-projetada e plateia (Gonçalves, 2013). Qualquer imprevisto precisa ser solucionado rapidamente, o espetáculo não pode parar: entre decodificações e saltos a vida da sessão é mantida, a 24 "pulsos" por segundo. Nesses instantes de "saltos", pospostos à uma decodificação, quando ao perceber hapticamente uma alteração em qualquer elemento da cabine, seja o transitar da película por entre os trilhos do projetor, ou um "foraquadro", ou o foco, ou o som, ou uma engrenagem, ou... No gesto de arremeter-se para proteger a vida da sessão, o projecionista semelha um bailarino. Sua desenvoltura corporal parece incorporar a "fantasmata", elemento medular da arte da dança, como percebida por Domenico da Piacenza - coreógrafo que viveu na Itália no século XV. Esse "fantasma", uma espécie de pausa, na qual o dançarino tensiona e concentra o corpo, medindo e memorizando os movimentos da coreografia, habita o "meio" de um movimento e outro.

\footnotetext{
Digo a ti, que quer apreender o ofício, é necessário dançar por fantasmata, e nota que fantasmata é uma presteza corporal, que é movida com o entendimento da medida [...] parando de vez em quando como se tivesse visto a cabeça da medusa, como diz o poeta, isto é, uma vez feito o movimento, sê todo de pedra naquele instante, e no instante seguinte cria asas como o falcão que tenha sido movido pela fome, segundo a regra acima, isto é, agindo com medida, memória, maneira com medida de terreno e espaço. (Domenico da Piacenza apud Agamben, 2007, p. 24)
}

Ver esta cabeça da medusa, remete a ver uma imagem memorizada, que recarrega o corpo do dançarino com energia, de modo que a dança assim apreendida, não se reduz apenas a movimentos, mas ao tempo, à vida que existe nas imagens e que devemos buscar compreender. Não se trata de visualizar imagens dispostas no tempo, mas de perceber que há tempo nas imagens, vida, portanto (Agamben, 2007, p. 25).

O desejo de Alexandro Genaro, roteirista e projecionista do curta-metragem Balé Mecatrônico, foi descortinar o tilintar temporal em uma cabine de projeção, mostrar "o tempo da cabine", e como tal ritmo difere da percepção do público, alocado na plateia. O script consistiu simplesmente na apresentação de seu "modo de fazer" ao conduzir a sessão de um longa-metragem em celuloide. Ele preparou a película, limpou trilhos e janelas, carregou o 
projetor e conduziu o espetáculo ao vivo; interagindo com o filme $35 \mathrm{~mm}$, a vinheta em formato digital e com o rito da sessão: a cadência do espetáculo atravessa seu corpo; a seu comando as cortina descem, as luzes apagam lentamente e as viagens dos espectadores com as imagens-projetadas começam. A câmera o acompanha, perscrutando seus movimentos, ensaiados exaustivamente a cada sessão, diariamente. Entre um movimento e outro, decodificações: pausas para "ver a cabeça da medusa" em "fantasmatas" e a seguir, deslocamentos rápidos afundando-se na escuridão da cabine. Por vezes a câmera o perde e segue um curso solitário. Depois encontram-se novamente, entrecruzando seus trajetos numa dança precisa e tensa, qualquer movimento em falso poderia colocar em risco a vida do espetáculo em jogo. Pensando com Gilles Deleuze: "não se trata de contar uma história num espaço e tempo determinados, é preciso que os ritmos, as luzes, os espaços-tempos devenham, eles próprios, verdadeiras personagens" (Deleuze, 2016, p. 305).

Noutros terrenos, a mudança da película para o digital também têm cambiado o ritmo da dança. Em um set de filmagem, para captar imagens através de uma câmera de película, é necessário que toda a equipe organize seu trabalho condicionada aos 10 minutos do rolo virgem de filme, tempo máximo para que a ação aconteça sem cortes. Se o rolo de filme termina, obrigatoriamente a equipe precisa realizar uma parada para recarregar a câmera. Além disso, não é possível visualizar ainda no set o que está sendo filmado, apenas horas depois, inviabilizando repetições. Com a mudança do suporte padrão para o digital, as imagens não são mais recolhidas granularmente por uma película fílmica, alterando completamente os manejos em um set cinematográfico, além de diminuir significativamente o orçamento para se produzir e distribuir filmes, produzindo assim, novos modos de fazer nos negócios que envolvem a sétima arte.

Além do baralhar das linhas mercadológicas, existem questões problemáticas no que tange à preservação de filmes em digital, pois ao longo de mais de cem anos de cinema, aprendeu-se a preservar os filmes enquanto objetos fílmicos em película. Na década de 80, os problemas eram outros, os profissionais da área sonhavam com condições adequadas de controle de temperatura e umidade. Agora, pensando que não haverá mais "um objeto fílmico a ser preservado" (ou seja, os rolos de filmes com suas variáveis já conhecidas), mas sim, arquivos de dados que precisam ser salvos em HDs (e para se manter salva uma imagem de qualidade, são necessários muitos Terabites, distribuídos em discos alocados fisicamente em algum local institucional), a conservação de um acervo audiovisual, passa da lógica da "preservação", para a "manutenção", pois, a partir do momento em que não se tem mais objetos para preservar, mas sim dados (pixels), as preocupações práticas e teóricas alteram-se substancialmente. Para complementar tal cenário, existe o fato de que as técnicas para "preservar" (manter?) arquivos de filmes digitais ainda não são de todo seguras (Ampas, 2009; Ampas, 2015). O cinema levou quase cem anos para se entender com seus suportes e técnicas de guarda, agora, a discussão é sobre o "como" e o "quando" da compreensão/ domínio destes novos paradigmas tecnológicos. O suporte padrão, de filme fotoquímico, está sendo substituído por pixels (Schisler, 2011). 
Uma câmera digital não utiliza o celuloide. Sob outra perspectiva, a luz é mensurada e coletada por pixels, pontos individuais que traduzem a luminescência em dados eletrônicos correspondentes à imagem captada. Assim, a mudança do corpo fílmico transmuta o território do que "é" o cinema, para outras interações, mediadas agora por um outro corpo, que chamaremos aqui de "corpo-pixel". Para além da disposição de imagens fotográficas no tempo, o corpo-pixel abre novos campos de possíveis, nos quais às buscas por imagens realistas, "fidedignas à realidade", passam a ser acrescidas outras nuances.

O cinema atravessa diversos territórios, como a pintura, a música, a literatura. (Deleuze, 2016, p. 302). Para além da ideia de movimentos de imagens organizadas no tempo, os cineastas inventam espaços, luzes e temporalidades visando agenciar o espectador às narrativas, "relações entre corpos se processam por sua capacidade de produzir afetos e de ser afetados" (Barbosa, 2015, p. 335). O cinema como um mecanismo do pensamento. Como se acionássemos uma espécie de projetor interno, um equipamento invisível, capaz de organizar num "devir abstrato" os cortes imagéticos que capturamos ao longo da vida (Deleuze, 1985).

Em uma sessão, os movimentos do aparelho (máquina técnica) continuam totalmente invisíveis se assistirmos ao filme da perspectiva da plateia. Mas, se subirmos as escadas rumo à cabine de projeção, experimentaremos da fricção entre espaço, máquinas e corpos, como se, parcialmente, o "segredo mágico" desse mecanismo fosse revelado. A ilusão de movimento na tela, pode, desta mirada, ser percebida através dessa dança, desse "balé mecatrônico" executado pelos corpos agenciados ao espaço da cabine.

Nas "danças" de nossas vidas, em um mundo no qual as interações acontecem cada vez mais por meio de telas (como os celulares inteligentes, os microcomputadores, as televisões interativas, as telas dos caixas bancários, etc), somos recorrentemente interpelados por chamamentos às conexões, continuamente (re)compondo e (re)configurando nossos corpos, de modo que, talvez o gesto de ir ao cinema, assistir a um filme sem interrupções, sem que outras luzes enfraqueçam a imagem-projetada, entregando-nos aos possíveis agenciamentos da sala escura, produza uma pausa do corpo, um intervalo, quiçá em "fantasmata" faceando a medusa, ativando produções de subjetividades imagéticas como espécie de combustíveis para o gesto seguinte da vida, aquele momento posterior descrito por Domenico da Piacenza, do falcão faminto que cria asas. Fome de vida. Modulando experiências vitais, movimentando o pensamento cinematograficamente: "O cérebro é a tela" (Deleuze, 2016, p. 300). Há “uma 'vida' reactivada no ecrã pelas diferentes modalidades do texto fílmico" (Azevedo, 2007, p. 364), que nos atravessa, nos provoca à vida das e nas imagens, ao(s) tempo(s) nelas enquadrado(s). E como se dão tais invitações? Acaso os pixels nos trespassam de modo diverso que os grãos de prata? Há quem diga que sim, mas continuam sendo corpos, produzidos pelo cinema, em grãos de tempo. 


\section{CORPO-PIXEL}

O espetáculo teatral Memento Mori (2015), praticamente nos convida a jogar uma partida de xadrez com a morte. Sombras projetadas misturam-se na tela, desfigurando representações, criando outros corpos, misturando fronteiras: "cada espectador se vê convidado a 'preencher', com sua própria bagagem e experiências de vida, as lacunas que os vultos projetados evocam, o que torna o teatro de sombras um dos mais fortemente imaginativos subgêneros teatrais"3. Tais imagens nos provocaram a pensar sobre a ideia do corpo como um suporte e também, do suporte como um corpo. Os corpos dos atores e de objetos cênicos como suportes do teatro de sombras, são atravessados pelos refletores, incidindo como as "imagens-projetadas" do cinema: o "corpo-suporte" posiciona-se entre a luz e a tela, princípio análogo ao de um projetor de películas.

O suporte também pode constituir-se como um corpo "fora da norma vigente", como hoje os filmes em base de nitrato de celulose, utilizados na primeira metade do século XX, que abrigam expressivas e importantes imagens e ao mesmo tempo são intolerantes ao calor, podendo entrar em combustão apenas com a elevação da temperatura ambiente, "sem a necessidade de uma chama para deflagrar o fogo [...] Uma vez iniciado, o fogo do nitrato atinge altas temperaturas e é "inextinguível"' (Coelho, 2009, p. 33-34). Corpos como suportes e suas singularidades. Aqui, já rumamos à ideia do suporte como um corpo. Um filme em película, pensando desta forma, constituir-se-ia como um corpo, que demanda processos de preservação para continuar existindo, tal qual outros corpos demandam.

A palavra "suporte" no meio cinematográfico, refere-se ao material que retém a imagem, tanto no momento da captação, quanto ao longo da vida do filme; "um plástico flexível, transparente e uniforme, que dá sustentação física à emulsão", que por sua vez, tratase de "uma camada de gelatina que abriga e mantém estável a substância formadora da imagem - grão de prata, no filme preto-e-branco, ou corantes, no filme colorido" (Coelho, 2006, p.18). Ebert (2010), faz uso da mesma palavra ao definir cinematografia e cinema digital, afirmando entender "por cinematografia digital a captação de imagens em movimento em suporte digital, e por cinema digital a exibição destas imagens". Assim, fica claro que o termo pode ser utilizado para fazer referência tanto a películas como por exemplo $35 \mathrm{~mm}$, 16mm e Super 8, ou para outros tipos, como DVCam, HDCam, BetaCam, etc. Souza (2009), ao abordar aspectos da preservação de filmes na Cinemateca Brasileira, faz uso do termo de forma mais abrangente ao apontar que em " 1985 , a história atropelara a Cinemateca Brasileira que, às voltas ainda com os problemas de conservação de matrizes em preto-ebranco e em cor, via-se agora envolvida com a preservação de imagens fixadas em suporte magnético" (Souza, 2009, p.170-171). Muitos profissionais também se utilizam do termo "formato".

${ }^{3}$ Disponível em: <http://espetaculomementomori.blogspot.com.br/2015_07_01_archive.html>. Acesso em: 27/08/2016. 
Os estudos acerca da preservação de objetos fílmicos têm rumado para a problemática da manutenção de dados. Mudam os corpos com os quais a preservação estava acostumada a lidar. Agora as imagens são produzidas, à largo, por pixels. Diante disso, poderíamos pensar em outros corpos, transversalizando a reflexão sobre os suportes. Ao invés de filmes como "corpos-películas", poderíamos considerar agora filmes como "corpos-pixels"? O cinema digital vindica corpos com outras trajetórias, outras marcas, outros agenciamentos, outros "campos de possíveis", e diz: "não precisamos mais dos 'corpos-películas', sua manutenção é custosa; não carecemos mais deles e nem de todo o aparato que os sustentam”. Neste ponto, o cinema digital e toda a atmosfera envolta, entra num embate direto com a cultura dos projecionistas e dos cineastas que defendem a película como suporte; como corpo-suporte; como ator principal do palco deste "teatro de sombras". Este movimento de rejeição aos corpos-películas, produz uma outra lógica, um universo diferente. São outros projetores, outros players, outros operadores cinematográficos, outras imagens do pensamento possíveis.

O cineasta Quentin Tarantino é categórico. Ele alega que o digital tem suas vantagens, mas está matando o cinema como o conhecemos e não é adequado a cineastas já estabelecidos, apenas a jovens sem recursos que queiram se expressar. Em 2015, seu filme "Os 8 Odiados" chamou atenção por ter sido captado e exibido, em alguns cinemas, no formato Ultra Panavision 70mm, "uma bitola com o dobro da largura do $35 \mathrm{~mm} \mathrm{[...],} \mathrm{a}$ projeção de uma imagem extremamente nítida, de uma riqueza de detalhes impressionante" (Salles, 2009).

O digital não é para mim. Eu não acho que é melhor algo filmado ou projetado em formato digital [...] Eu sempre acreditei na mágica dos filmes. A magia dos filmes está ligada ao $35 \mathrm{~mm}$, porque quando você grava um filme, você não está gravando o movimento: você está apenas tomando uma série de imagens estáticas, não há nenhum movimento nos filmes de maneira geral! Quando essas imagens são mostradas a 24 frames por segundo, atravessadas pela luz de uma lâmpada, elas te dão a ilusão de movimento: todos vocês estão vendo uma ilusão, a impressão em um filme, e essa ilusão está conectada à magia dos filmes. ${ }^{4}$

O diretor húngaro László Nemes, alonga-se na questão: não concebe o digital como cinema. Por isso rodou seu filme "O filho de Saul”, de 2015, em película 35mm.

Para mim, o cinema é película. É algo que conversei muito com o diretor de fotografia Mátyás Erdély. O digital não é cinema. Você vai comprovar isso daqui a vinte anos, quando não conseguir abrir o arquivo de um filme feito no ano 2000 . O cinema precisa do suporte físico e da magia luminosa da projeção. A imagem digital é muito clara, dá a impressão de estar lá, mas a projeção cinematográfica precisa da projeção emocional. E esse envolvimento emocional é essencial. Eu acho que todo esse assunto do digital é uma farsa em que o espectador acaba obtendo menos. É a primeira vez na história do cinema que o progresso técnico representa de fato uma regressão. ${ }^{5}$

\footnotetext{
4 “Quentin Tarantino comments on Digital vs Film”. Disponível em <https://www.youtube.com/watch?v=BON9Ksn1PqI>. Acesso em: 08 ago. 2016. Tradução nossa.

5 "László Nemes: 'El cine digital es una estafa, una regresión”". Disponível em: <http://www.elcultural.com/revista/cine/LaszloNemes-El-cine-digital-es-una-estafa-una-regresion/37482>. Acesso em: 28 ago. 2016. Tradução nossa.
} 
David Lynch, diz que o excesso de controle sobre a imagem digital ao longo da filmagem altera o processo de feitura de um filme. Por estar acostumado a captar imagens em celuloide, ciente de que o corpo-película provoca uma ligeira perda, além de um certo distanciamento (dado que só é possível visualizar o que foi captado horas depois), ele diz lidar com uma porcentagem de perda que o permite interagir com a luz e os elementos cênicos de outra maneira ${ }^{6}$. Portanto, uma interação singular com a produção imagética.

E por que em nossos dias, assistimos à substituição radical dos "corpos-película" pelos "corpos-pixels"? O cinema digital justifica-se: a lógica mudou! O discurso mudou! O saber-poder mudou! A regência entrega o bastão agora a outros percursos. Nesse movimento, uma contínua produção discursiva competitiva, de novos modelos de negócios que não utilizam mais a tecnologia que tem a película como corpo-suporte e supervalorizam o digital, priorizam o corpo-pixel, agora como o "corpo da vez", o "corpo da norma". Universos em atrito, compartilhando do mesmo tablado, "o que complica tudo, é que a mesma forma serve ao criativo e ao comercial" (Deleuze, 2016, p. 304).

Importante não desconsiderarmos que o processo de digitalização em curso não está contido apenas no terreno cinematográfico. A informática espraia diariamente seus domínios, está presente nos celulares, nos computadores, automóveis, em eletrodomésticos e toda a gama de pesquisas acerca das tecnologias ubíquas. Mas urge esquivarmos dos binarismos: "Ah! Então os que defendem o cinema digital são "capitalistas malvados"! Eles querem acabar com os corpos! Vamos lutar pela manutenção dos corpos, vamos defender o corpopelícula!". Esse discurso existe e tem seu vigor. A substituição de um suporte padrão pelo outro, concorrencialmente estabelece atritos que tendem a fragilizar os corpos-película, inclusive por não se encaixarem com a cultura contemporânea dos gadgets e conexões corpos-máquinas. Os corpos-película movimentam-se em tempos e dispositivos outros, sugerindo, porventura, mais movimentos de "fantasmata" em seu trato. Existem importantes saberes, questões políticas e estéticas em jogo. A questão dos custos mais elevados para a manutenção do aparato que mantém a vida dos corpos-película, (como os investimentos necessários às cinematecas) não deveriam ser a única tônica do discurso a sustentar uma suposta "superioridade" dos corpos-pixels, seguida de uma onda de destruição dos corpospelícula: troquemos as lentes, enquadremos as especificidades das experiências também. Inclusive porque os modos de fazer da preservação de imagens via corpos-pixel ainda não estão consolidados: o celuloide continua sendo o suporte mais seguro para conservação de imagens em longos períodos de tempo.

Um dos argumentos de defesa do digital é o fato de que um espectador que não interage tecnicamente com as imagens - o tipo de suporte, as cores, a montagem, etc - vai ao cinema para apreender o filme de outras maneiras, com outros pontos de vista: "relações produtoras de mapas abertos aos encontros" (Barbosa, 2015, p. 335). Uma possibilidade dessa apreensão (que com certeza também não é a única) dar-se-ia por interações mais

6 “David Lynch on Digital Video Versus Film". Disponível em <https://www.youtube.com/watch?v=pjtnOCfuPVQ>. Acesso em: 10 jun. 2016.

\begin{tabular}{l|l|l|l|l|l|l|} 
(C) ETD - Educ. Temat. Digit. & Campinas, SP & v.18 & n.4 & p. 835-855 & out./dez.2016 & ISSN 1676-2592 \\
\hline
\end{tabular} 
próximas à narrativa, à estória, aos personagens, aos espaços. Como em Cazetta (2013): “Há linhas, algumas invisíveis, outras mais pulsantes, nos atravessando. Somente aquelas sob as quais nos deixaremos afetar é que, de fato, possibilitarão o exercício e a experimentação do risco... do movimento da vida" (p. 30).

Para este espectador, não interessa se a imagem foi captada ou é exibida em película ou em digital. Sua relação constitui-se de outra maneira, por meio de outras "chaves de leitura". E mesmo algumas pessoas que preferem o cinema realizado com corpos-película continuam frequentando salas de cinema. É o caso de Ubirajara Zambotto, técnico especializado na manutenção de projetores, que também não considera o cinema digital como sendo cinema, por tratarem-se de outros processos, outras maneiras de processar e projetar as imagens. Por isso ele percebe no digital uma "imagem muito fria", que pode ser uma outra coisa, com outro nome e, apesar dessa "tristeza" que as imagens digitais the provocam, ele continua indo ao cinema, para encontrar os amigos, a família: "o que importa é aquela socialização, junto com as pessoas, com a tela grande" ${ }^{7}$. Como nos disse o projecionista César Sebastião Ramos, enquanto houver plateia o cinema permanecerá vivo: "O cinema é a plateia!"”.

Para além de dicotomias, a mudança tecnológica não é simplesmente boa ou má, depende dos agenciamentos produzidos. Se conseguirmos inventar novos territórios podemos caminhar para movimentos interessantes (Guattari, 2012). Considerar apenas um ou outro ponto de vista, nos posiciona num simplismo analítico, desconsiderando percepções outras sobre os corpos-suportes, a partir do momento em que negamos quaisquer corpos que fujam do estereótipo. Podemos facilmente cair numa forqueadura analítica, tomando o corpo-pixel como "melhor" que o corpo-película e da mesma maneira, afirmando que o corpo-película é o único cinema possível.

Para pensar nessas diferenças, talvez, nos auxilie a mirada de Bazin (2014), ao tratar da transição do cinema mudo para o sonoro. Ele relata um sentimento de estranhamento de alguns, de que o cinema, ou ao menos um determinado cinema, teria morrido pela inserção do som. Esse desespero estava associado à ideia do cinema mudo como "uma arte completa", na qual o silêncio, enquanto um "delicado incômodo" daria à arte muda estilos diferentes do cinema sonoro, de modo que "o som só poderia, no máximo, desempenhar um papel subordinado e complementar: como contraponto à imagem visual” (Idem, p. 98). Mas Bazin acreditava que a importante clivagem não estava aí. A imagem sonora por ter uma vocação realista, teria craquelado um modo de fazer "tanto o expressionismo plástico quanto as relações simbólicas entre as imagens" (Idem, p. 105). O cinema falado então teria anunciado "a morte de uma determinada estética da linguagem cinematográfica, mas somente daquela que mais o distanciava de sua vocação realista" (Idem, p. 111). Cinema mudo e sonoro como experiências diferentes, e no contexto contemporâneo, o digital também evocando outros percursos, que podem não ser excludentes.

${ }^{7}$ Excerto obtido por entrevista gravada em áudio, dia 03/10/2015, cujo entrevistado assinou termo de concessão.

${ }^{8}$ Excerto obtido por entrevista gravada em áudio, dia 14/10/2015, cujo entrevistado assinou termo de concessão.

\begin{tabular}{l|l|l|l|l|l|l|}
\hline (C) ETD - Educ. Temat. Digit. & Campinas, SP & v.18 & n.4 & p. 835-855 & out./dez.2016 & ISSN 1676-2592 \\
\hline
\end{tabular} 
A própria inserção das tecnologias mecânicas nos modos de fazer artísticos já produziram inquietações. Como se as tecnologias reorganizassem artificialmente as experiências, desestruturando "o carácter único das representações e, consequentemente, o carácter único de cada lugar fixado em paisagem" (Azevedo, 2007, p. 326), permeabilizando fronteiras outrora fixas da ideia de autenticidade de uma imagem. Se, por um lado a possibilidade de reproduzir a obra possibilitava sua preservação, por outro era tido como algo ameaçador, uma dessacralização da "originalidade" e da "aura" das obras de arte.

\begin{abstract}
A percepção da reprodutibilidade de uma obra pela tecnologia, e portanto da decadência da aura prefigurava-se, assim, como um factor sintomático da transformação cultural e da revolução na estrutura da experiência. E isto era uma ameaça à própria identidade das obras, que perdendo a sua identidade fixa se tornavam completamente permeáveis ao contexto de produção e recepção. A ameaça que as novas tecnologias estabeleciam pela permeabilização do significado e do estatuto da obra de arte, configurava pois uma ameaça à destruição de uma identidade pré-estabelecida por códigos e convenções dominantes. A crise engendrada pela dissolução da identidade de um objecto pela permeabilização das suas fronteiras levaria, portanto, a um movimento de lamentação que operava em sentido contrário ao da dissolução da aura, pela monumentalização das imagens "únicas" como expressão de um modelo "autêntico" de experiência. (Azevedo, 2007, p. 326).
\end{abstract}

Em nossos dias, vivemos movimentos semelhantes, novamente com uma tecnologia produzindo desterritorializações das experiências subjetivas, via os processos de digitalização dos fazeres artísticos. Existem instigantes filmes sendo produzidos e exibidos em digital, que da perspectiva da captação de imagens, elimina diversas barreiras inerentes à película, que, por sua vez, possui nuances alheias ao digital, que, por sua volta, tem ampliado a produção diminuindo custos, expandindo o acesso, produzindo novas janelas, etc. Essa própria pesquisa não poderia celebrar o fato de ter produzido imagens se não fosse por tal tecnologia. Não disporíamos de recursos e nem mesmo seria cabível no contexto contemporâneo da universidade produzir imagens por meio de corpos-película.

Alguns exemplos de transversalidades possíveis aos corpos-pixel: o filme "Tangerine", de 2016, dirigido por Sean Baker. Filmado com um celular Iphone5 e sobre travestis, contorcendo assim, a ideia de corpos humanos e não humanos "fora da norma". A câmera adentra territórios e produz movimentos que provavelmente câmeras mais robustas inviabilizariam. Por exemplo, num enquadramento miramos internamente a uma estufa de "donuts", a conversa dos personagens em uma loja de doces. Há planos externos com a câmera em movimento, seguindo o ritmo frenético dos atores, que seriam no mínimo bastante custosos se produzidos ou por câmeras digitais robustas ou por câmeras de celuloide. Traquitanas complexas foram substituídas pelo manejar dos dedos em uma câmera de celular, com o auxílio de um pequeno adaptador para simular a imagem anamórfica; um aplicativo (Filmic Pro), para controlar a granulação e a temperatura das cores; uma steadicam para Iphones, para estabilizar a imagem no momento da captação; na pós-produção, saturaram as cores, inventando novas possibilidades para o universo narrativo: "Nós saturamos as cores até 
não poder mais — já que o mundo [do filme] é incrivelmente colorido, as mulheres são cheias de cores" 9 .

Outro exemplo interessante com corpos-pixel, se dá na feitura do filme "Waking Life", de Richard Linklater (2001). As imagens foram captadas com uma câmera de vídeo e posteriormente trabalhadas com uma versão digital da técnica chamada rotoscopia, na qual são feitas sobreposições a partir da imagem gravada previamente. A narrativa do filme, que propõe um mergulho filosófico por meio de longas conversas entre o personagem principal e pessoas que ele encontra em sonhos, com essa intervenção "rotoscópica" adquiriu uma amplitude estética convergente às conversações.

Corpo-pixel como um corpo com pujantes possibilidades de entrada e "aberturas", possibilitando incontáveis cópias e replicações. Camadas imagéticas que podem criar universos outros ou mesmo deformar a própria representação convencional do corpo humano, como no videoclipe da música "Wide Open"10, do duo de música eletrônica Chemical Brothers, no qual o corpo da dançarina Sonoya Mizuno passa por mutações ao longo da dança. Conforme música e bailado se desenrolam, o corpo "humano" de Sonoya vai mudando para um corpo construído por softwares. O corpo da dançarina foi minuciosamente escaneado para a construção de um corpo "virtual". O espaço também foi mapeado via softwares. A imagem, decomposta em diversas camadas, intercala o galpão em que a dança acontece, vazio, e com a presença da bailarina. O corpo que inicia completamente "humano", transita para outra forma, primeiro a perna, os braços, o tronco. Ao final da dança, apenas o corpo "virtual" baila no galpão ${ }^{11}$.

Nesta dança percebemos uma característica interessante dos universos de possíveis que as imagens digitalizadas abarcam. Um corpo-pixel pode ser copiado, decomposto, duplicado, replicado, "furado", deletado e, se, cópias de alta qualidade forem preservadas (e aqui, como dito, temos problemáticas insolvidas na preservação), ele continua de certo modo "vivo". Quanto à preservação dos corpos-pixel, trata-se de um processo recente e diferente daquele que preserva os corpos-película, o qual ainda não tem amplamente às claras seus modos de fazer (Ampas, 2009; Ampas, 2015; Schisler, 2011). Se tomarmos um corpopelícula, também conseguiremos realizar manualmente intervenções e efeitos especiais nas imagens-projetadas, entretanto, tratam-se de processos diferentes, artesanais e arriscados ao desgastar dos corpos e de perdas nas tentativas. Com as tecnologias digitais, espraiam-se as possibilidades de desvirtuar o status de realidade das imagens, de desconfigurar até mesmo as representações convencionais dos corpos humanos via corpos-pixel. "A história da humanidade é sempre história de fantasmas e imagens [...] como é na imaginação que algo

9 "Tangerine: como chegar ao Sundance Film Festival com uma câmera de iPhone". Disponível em: <http://www.tecmundo.com.br/cinema/73295-tangerine-chegar-sundance-film-festival-camera-iphone.htm〉. Acesso em: 24/05/2016.

10 "The Chemical Brothers - Wide Open ft. Beck". Disponível em: 〈https://www.youtube.com/watch?v=BC2dRkm8ATU>. Acesso em: 25/01/2016.

11 "Behind the Scenes: The Chemical Brothers "Wide Open'". Processo detalhado neste vídeo, disponível em: <https://vimeo.com/154038415>. Acesso em: 07/02/2016.

\begin{tabular}{l|l|l|l|l|l|l} 
(C) ETD -Educ. Temat. Digit. & Campinas, SP & v.18 & n.4 & p. 835-855 & out./dez.2016 & ISSN 1676-2592
\end{tabular}


como uma história se tornou possível, é por meio da imaginação que ela deve, cada vez, de novo se decidir" (Agamben, 2007, p. 63).

Saem as bobinas e entram os players, ausentam-se os grãos de prata e irrompem os pixels e continuamos lidando com imagens carregadas de tempo. Mas de que maneira pensamos (n)esses movimentos? O cineasta Edward Lachman lança a questão: "estamos contando histórias com imagens através da câmera ou a partir de um computador?"12. E emendamos: temos via corpos-pixel mais possibilidades de desterritorializações e de entradas às imagens do pensamento, dados os múltiplos agenciamentos e miradas proporcionados pela tecnologia do cinema digital? Depende, como dito por Guattari, de qual é o agenciamento produzido. Uma possível chave: agenciar arte e técnica. Ampliemos: há múltiplas possibilidades se movimentarmos nosso pensamento de modo transversal e rizomático.

Multiplicidades de corpos com marcas e "materiais gelatinosos", "grudados". Múltiplos universos de subjetividade(s): formadores de imagens projetadas nos "ecrãs" da vida. Telas estas que percebemos e que outros também percebem, nem sempre da mesma maneira, nem sempre, nem mesmo, de maneiras parecidas. Não ignoremos os discursos dos negócios e do corpo-pixel como "corpo da vez", o cinema também é percebido desta perspectiva, mas, se calcados apenas na fúria mercadológica, podem nulificar o discurso da importância dos corpos-película, excluindo-os do(s) jogo(s). Vide os poucos recursos destinados aos museus e cinematecas. E nestas últimas, os incêndios, e o fogo queimando os acervos... Vindicamos produzir torções nas possibilidades de análise, provocar invenções/inversões de territórios, transversalizar portas de entrada em "rizomas imagéticos", "jorrar problemas e questões nos quais somos tomados, mais do que dar respostas" (Deleuze, 2016, p. 305).

\section{CONSIDERAÇÕES FINAIS}

No momento do espetáculo ao vivo, o corpo do projecionista agencia-se aos maquinários da cabine de projeção, estabelecendo uma relação singular com a imagemsuporte e a imagem-projetada; em uma ponta o celuloide como material de trabalho; na outra, a imagem-projetada na tela; no meio, escolhas, codificações e decodificações cingidas pelo "modo de fazer" de cada projecionista. Quando o projetor é acionado, o feixe de luz atravessa a sala escura e permeia a tela branca, projetando assim as imagens "grudadas" no corpopelícula. O manejo das exibições digitais, convoca outros saberes, embaralhando as cartas no jogo dos projecionistas. Os corpos mudam e os agenciamentos também. As estratégias de trabalho, para que as imagens-suporte desenrolem-se em imagens-projetadas, relacionam-se propriamente às interações do operador com os corpos fílmicos. Se corpo-película (películas $70 \mathrm{~mm}, 35 \mathrm{~mm}, 16 \mathrm{~mm}$, Super-8, etc), demandará manuseio, montagem, emenda dos rolos, limpeza dos projetores, carregamento, exibição e desmontagem. Se corpo-pixel, um roteiro

12 “'Are We Telling Stories with Images through the Camera or from a Computer?' Ed Lachman on Shooting Carol in Super 16mm". Disponível em: <http://filmmakermagazine.com/97325-are-we-telling-stories-with-images-through-the-camera-or-from-acomputer-ed-lachman-on-shooting-carol-in-super-16mm/\#.VsJAr3QrL-1>. Acesso em: 26/02/2016. 
de trabalho diverso é delineado: os filmes são transferidos ao servidor, posicionados na playlist, exibidos e deletados. Essas mudanças afetam diretamente a profissão dos operadores cinematográficos, pois a miríade de conhecimentos necessária a "um bom operador" (como exemplo: noções de eletricidade, mecânica, ótica, preservação, fotografia, áudio), tem sido removida da ordem do dia: o corpo-pixel agenciado aos computadores e projetores do digitais avessam tal raciocínio.

O cinema digital tem adulterado essas "fantasmatas" dos projecionistas. Já que a máquina "faz tudo", se um projetor falhar em meio à exibição de um filme, esse "salto", talvez seja feito com outros gestos, de outros jeitos, ou talvez a incidência de falhas ao vivo diminua, ou.... Conjuntos de "telas + hardwares + softwares" adensam e estorvam o modo de fazer de diversas tarefas diárias, inutilizando saberes de operadores mais experientes, agora taxados de "velha guarda".

Muda o saber da vez, muda o corpo da norma. As tecnologias atravessam nossos processos de subjetivação e repertórios imagéticos, contaminando-nos os corpos e as experiências, em pulsações (des)contínuas: "Começa e termina no corpo. Neste há camadas e mais camadas de histórias, de trajetórias, de marcas. As marcas que marcam o corpo são diferentes das marcas que marcam o espaço, mas ambas estão implicadas. No acontecer da vida elas são inseparáveis" (Cazetta, 2013, p. 20).

Habitar "fantasmatas" como quem habita intervalos entre geografias e cinemas. O corpo humano, como suporte, acolhe marcas, simultaneidades de "estórias-até-agora" (Massey, 2008), representações, experiências, "afe(c)tos", forças, identidades, e... ao ser atravessado por "feixes de luz", "projeta" essas imagens (ao vivo!) nas "telas" da vida, provocando, como no cinema, sensações múltiplas, inclusive de movimento. No caso do cinema, a 24 quadros por segundo. Cotidianamente, a 24 horas por dia.

Não restam dúvidas de que os modos de fazer dos projecionistas mudam drasticamente nesse novo contexto. Seus saberes têm sido desterritorializados, em muitos casos até invalidados e demissões em massa têm acontecido, por muitos desses profissionais ou não saberem, ou mesmo em alguns casos, recusarem-se a operar cabines de projeção com o digital como corpo-suporte. Manejar playlists e apertar botões, pode ser projeção? Cinema digital, pode ser cinema? E se mudarmos o "como", contorcendo o movimento do pensar para outros giros? Estanciando em "fantasmatas" neste baile hodierno? O próprio curta-metragem Balé Mecatrônico, ao invitar à dança com corpos-película consubstanciando-se num corpopixel, pode ser cinema? O bailado de uma câmera pequena, de resolução mediana, que se imiscuiu pari passu ao projecionista, em tomadas que penetraram entranhas escuras da cabine de projeção, por vezes evidenciando sua baixa definição pixelizada por borrões e quadrados à vista, mas ali, carregando as imagens com "o tempo da cabine", fundindo-se à escuridão em movimentos de pedras, fantasmas e falcões. É? 
Temos aumentado o ritmo da(s) dança(s) dos corpos fílmicos. As imagens fotoquímicas dos "grãos de tempo" - auras realistas de corpos que, a seu modo, "estiveram lá", verificaram a luz e capturaram imagens com mais condições de invocar discursos de veridicção -, assistem à erupção dos corpos-pixel, suportes com possibilidades alargadas de desterritorializações imagéticas, ou replicações, ou invenções de territórios, ou diegeses nunca dantes navegadas, ou... Rasgando, em muitos feitos, evocações a supostos status de realidades. Podem ademais, de certo modo, nem mesmo precisar da "luz real" para existir...

Produzir movimentos de pensamento em "fantasmatas", diante da excessiva velocidade da produção imagética de nossos dias. Talvez para "coreo-geo-grafar" espaços outros, navegando hapticamente em campos de possíveis inexplorados, experimentando "modos de fazer": "sê todo de pedra naquele instante, e no instante seguinte cria asas como o falcão que tenha sido movido pela fome" (Domenico da Piacenza apud Agamben, 2007, p. 24). Lembra-te, ademais, dos passos dos projecionistas, nesta dança com os corpos fílmicos.

\section{REFERÊNCIAS}

AGAMBEN, Giorgio. Ninfas. Tradução de Renato Ambrosio. São Paulo: Hedra, 2007.

AMPAS - ACADEMIA DE ARTES E CIÊNCIAS CINEMATOGRÁFICAS. O dilema digital: questões estratégicas na guarda e no acesso a materiais cinematográficos digitais. AMPAS: Estados Unidos, 2007. Trad. Cinemateca Brasileira, São Paulo: Cinemateca Brasileira, 2009.

O dilema digital 2: perspectivas de cineastas independentes, documentaristas e arquivos audiovisuais sem fins lucrativos. AMPAS: Estados Unidos, 2012. Traduzido por Millard Schisler; Osvaldo Emery e Patricia de Filippi. São Paulo: Instituto Butantan, 2015.

AUMONT, Jacques. A imagem. Tradução de Estela dos Santos Abreu e Cláudio C. Santoro. 2a ed. Campinas, SP: Papirus, 1995.

AZEVEDO, Ana Francisca de. Geografia e cinema: representações culturais de espaço lugar e paisagem na cinematografia portuguesa. Braga: Repositorium - Universidade do Minho, 2007. Disponível em: <http://hdl.handle.net/1822/6715>. Acesso em: 20/08/2016.

AZEVEDO, Ana Francisca de; RAMÍREZ, Rosa Cerarols; OLIVEIRA Jr., Wenceslao Machado. Intervalo I: entre geografias e cinemas. Braga, Portugal: Editora UMDGEO Departamento de Geografia da Universidade do Minho, 2015. Disponível em: <http://hdl.handle.net/1822/35539>. Acesso em: 20/08/2016.

A LUZ dos vaga-lumes. [Fotografia]. Ingrid R. Gonçalves. Brasil. 2015. Disponível em: <https://www.flickr.com/photos/balemecatronico/albums/72157665898001032>. Acesso em: 20/08/2016.

BARBOSA, Cristiano. As fronteiras movediças de Israel nos documentários de Amós Gitai. In: Intervalo I: entre Geografias e Cinemas. 1ed.Braga (Portugal): UMDGEO Departamento de Geografia, Universidade do Minho, 2015, v. 1, p. 315-338. 
BALÉ MECATRÔNICO. [Curta-metragem]. Ingrid Rodrigues Gonçalves / Coletivo Balé Mecatrônico. Brasil. Duração: 19'16”. 2014. Disponível em:

<https://www.youtube.com/watch?v=WKNmcGVR8iE>. Acesso em: 20 ago. 2016.

CAZETTA, Valéria. As coreo-geo-grafias em Pina: para fazer a geografia dançar. EntreLugar, Dourados, v. 4, n. 7, p. 19-31, 2013. Disponível em:

<http://www.producao.usp.br/handle/BDPI/45566>. Acesso em: 21/08/2016.

COELHO, Fernanda. Manual de manuseio de películas cinematográficas: procedimentos utilizados na Cinemateca Brasileira. 3. ed. São Paulo: Imprensa Oficial do Estado :

Cinemateca Brasileira, 2006.

COELHO, Maria Fernanda Curado. A experiência brasileira na conservação de acervos audiovisuais: um estudo de caso. Dissertação (Mestrado). Escola de Comunicação e Artes, Universidade de São Paulo, USP. São Paulo, 2009.

DELEUZE, Gilles. Dois regimes de loucos: textos e entrevistas (1975 - 1995). Ed. David Lapoujade. Trad. Guilherme Ivo. Rev. Luiz. B. L. Orlandi. São Paulo: Editora 34, 2016.

DELEUZE, Gilles. Espinosa: filosofia prática. São Paulo: Escuta, 2002.

DELEUZE, Gilles. Cinema 1: A Imagem-movimento. Trad. Estella Senra. São Paulo: Editora Brasiliense, 1985.

DELEUZE, Gilles; GUATTARI, Félix. (2012). Mil Platôs - capitalismo e esquizofrenia 2, vol. 5. Tradução de Peter PálPelbart e Janice Caiafa. São Paulo: Editora 34.

EBERT, Carlos. Cinema Digital - Introdução. Associação Brasileira de Cinematografia, ABC, 2010. Disponível em <http://www.abcine.org.br/artigos/?id=136\&/cinema-digital-introducao>. Acesso em: 24 ago. 2016.

GONÇALVES, Ingrid Rodrigues. Artesãos da imagem: os projecionistas e suas geografias. In: Anais III Colóquio Internacional "A educação pelas imagens e suas geografias". Vitória Espírito Santo, 2013.

GUATTARI, Félix. Caosmose: um novo paradigma estético. Trad. Ana Lúcia de Oliveira e Lúcia Cláudia Leão. São Paulo: Ed. 34, 2012.

MASSEY, Doreen. Pelo Espaço: Uma nova política da espacialidade. Trad. de Hilda Pareto Maciel e Rogério Haesbaert. Rio de Janeiro: Bertrand Brasil, 2008.

MEMENTO MORI: um ensaio para a morte. [Teatro]. Rodrigo Emanoel Fernandes/ Companhia da Sombra. Brasil. 60 minutos. 2015.

SALLES, Filipe. Bitolas e Formatos no Cinema. Mnemocine. 02 mai. 2009. Disponível em <http://www.mnemocine.com.br/index.php/cinema-categoria/28-tecnica/146-bitolasformatos>. Acesso em: 07 jan. 2016.

Palestra de Millard SCHISLER - A digitalização como técnica de preservação. (2011). 16 out. 2011. Youtube. Disponível em: 〈https://www.youtube.com/watch?v=4UnNNg6-PEM>. Acesso em: 07 ago. 2015. 
SLOANE, T. O'Conor. Motion picture projection. New York: Falk Publishing, 1922.

SOUZA, Carlos Roberto de. A Cinemateca Brasileira e a preservação de filmes no Brasil. 310p. Tese (Doutorado). Escola de Comunicações e Artes/USP. São Paulo, 2009.

\section{AGRADECIMENTOS}

Agradecemos às inenarráveis contribuições dos projecionistas Alexandro Nascimento Genaro e Carmen Lucia Genaro. Corpos que dançam: dois bailarinos desta dança hodierna.

\section{INGRID RODRIGUES GONÇALVES}

Bacharela em Gestão de Políticas Públicas

Escola de Artes, Ciências e Humanidades da Universidade de São Paulo - EACH, USP

São Paulo, SP - Brasil

E-mail: ingridgoncalves85@gmail.com

Recebido em: 07/09/2016

Aprovado para publicação em: 20/09/2016

Como citar este artigo:

GONÇALVES, Ingrid Rodrigues. Uma dança dos corpos fílmicos. ETD - Educação Temática Digital,

Campinas, SP, v. 18, n. 4, p. 835-856, nov. 2016. ISSN 1676-2592. Disponível em:

<http://periodicos.sbu.unicamp.br/ojs/index.php/etd/article/view/8646440>. Acesso em: 16 nov. 2016. doi:http://dx.doi.org/10.20396/etd.v18i4.8646440. 